Article

\title{
Development of Thermal Performance Metrics for Direct Gas-Fired Circulating Heaters
}

\author{
Benjamin C. Smith (D), Brett C. Ramirez *(D) and Steven J. Hoff \\ Department of Agricultural and Biosystems Engineering, Iowa State University, Ames, IA 50011, USA; \\ bcsmith1@iastate.edu (B.C.S.); hoffer@iastate.edu (S.J.H.) \\ * Correspondence: bramirez@iastate.edu; Tel.: +1-515-294-0468
}

Citation: Smith, B.C.; Ramirez, B.C.; Hoff, S.J. Development of Thermal Performance Metrics for Direct Gas-Fired Circulating Heaters. Agriculture 2021, 11, 588. https:// doi.org/10.3390/agriculture11070588

Academic Editor: José Pérez-Alonso

Received: 26 April 2021

Accepted: 22 June 2021

Published: 24 June 2021

Publisher's Note: MDPI stays neutral with regard to jurisdictional claims in published maps and institutional affiliations.

Copyright: (c) 2021 by the authors. Licensee MDPI, Basel, Switzerland. This article is an open access article distributed under the terms and conditions of the Creative Commons Attribution (CC BY) license (https:// creativecommons.org/licenses/by/ $4.0 /)$.

\begin{abstract}
Many climate-controlled agricultural buildings use direct gas-fired circulating heaters (DGFCH) for supplement heat. There is no standardized test to calculate thermal efficiency for these heaters. This study aimed to develop a measurement system and analytical analysis for thermal efficiency, quantify the measurement uncertainty, and assess economics of DGFCH efficiency. The measurement system developed was similar to the ASHRAE 103 standard test stand with adaptations to connect the apparatus to the DGFCH. Two different propane measurement systems were used: input ratings $<30 \mathrm{~kW}$ used a mass flow system and input ratings $>30 \mathrm{~kW}$ used a volumetric gas meter. Three DGFCHs $(21.9,29.3,73.3 \mathrm{~kW})$ were tested to evaluate the system. Thermal efficiencies ranged from $92.4 \%$ to $100.9 \%$. The resulting uncertainty (coverage factor of $2 ; \sim 95 \%$ Confidence Interval) ranged from $13.1 \%$ to $30.7 \%$ for input ratings of 56.3 to $11.4 \mathrm{~kW}$. Key sources of uncertainty were propane and mass flow of air measurement. The economic impact of $1 \%$ difference in thermal efficiency ranged from USD $\$ 61.3$ to $\$ 72.0$ per heating season. Refinement of the testing system and procedures are needed to reduce the uncertainty. The application of this system will aid building designers in selection of DGFCHs for various applications.
\end{abstract}

Keywords: heating cost; thermal efficiency; uncertainty

\section{Introduction}

The use of Direct Gas-Fired Circulating Heaters (DGFCH) is common in climatecontrolled agricultural buildings (e.g., livestock, poultry, and greenhouses) as the heating component of the thermal environment modification system. Supplemental heat is needed to achieve the environmental control goal in an agricultural setting, that is, maintain an ideal environment for the growth of the agriculture commodity with minimal cost [1]. For both animal confinement buildings and greenhouses, heating during the winter months is necessary to maintain the optimal environment and presents a significant utility cost [1,2]. In most building types, a forced air, circulating style heater is used to provide circulation of the heated air to the occupied zone within the building. Gas-fired heaters are ubiquitous due to low operating costs and fuel availability to remote locations [2]. While DGFCH are popular for agricultural applications, there are downsides in implementing them.

DGFCH are simple heaters in comparison to residential units based on the construction and operation principles. DGFCHs use a propane burner manifold placed on the intake of a blower. This does not the vent the combustion gases out of the occupied space. The output of the blower can be equipped with various directional vanes to aid in the distribution of heated air. The placement of such heaters in agricultural buildings is highly variable with no standardized placement design currently available in literature $[1,3]$. Thermal efficiencies of DGFCHs are commonly reported with assumed values of approximately $99 \%$; however, the water vapor and ventilation rates of a building can decrease the thermal efficiency to $80 \%$ [4]. In comparison to residential combustion heaters, which indirectly transfer heat to the air stream via a heat exchanger and combustion gases are vented 
outdoors, [5]. The use of the heater exchanger reduces the thermal efficiency to a range of $65 \%$ to $80 \%$.

DGFCHs are direct-fired, resulting in combustion gases (i.e., $\mathrm{CO}$ and $\mathrm{CO}_{2}$ ) formed directly in the heated air. In agricultural applications, the occupied (animal or plant) spaces where DGFCHs are present are continuously ventilated, unlike residential applications. The use of DGFCHs in greenhouses could result in safety concerns for workers, if prolonged operation throughout a day is necessary due to lower ventilation rates per floor area compared to animal buildings [4]. ANSI/ASHRAE [5] define the residential furnace thermal efficiency standard; however, there is limited standard thermal efficiency testing standards and guidelines for DGFCHs. Standardization of thermal efficiency testing and calculation allow for accurate comparison of different DGFCHs designs and capacities as well as generate informative equipment design specifications to support improved supplement heat capacity sizing and layout for agricultural buildings.

There are two types (direct and indirect) of combustion tests used to determine thermal efficiency. The direct test is a measure of the enthalpy gain of the air heated by the heater. Thermal efficiency can then be determined by dividing enthalpy gain by the sum of the heating fuel gross energy and electrical energy of the blower. This ratio of energy output over energy input for a given heater is the most accurate definition of thermal efficiency as the unit must obey the conservation of energy. The indirect test is a measure of the heating value of the fuel to determine the heat output less the flue gas or combustion gas enthalpy gain [5]. There are several challenges associated with applying the indirect test methodology to evaluate DGFCHs as the flue gas is mixed with the output air. The thermal efficiency calculated with the indirect methods typically is less accurate due to measurement error. Thus, DFGCHs are most appropriately evaluated by direct test methodology.

The objectives of this study were to (1) develop and validate a testing system and analytical analysis for determining the steady-state thermal efficiency of a DGFCH through a direct testing method; (2) evaluate the testing system across a range of DGFCH units; and (3) evaluate the economics of various DGFCH for agricultural uses.

\section{Materials and Methods}

\subsection{Thermal Efficiency}

The following sections will describe the methodology used to develop a DGFCH thermal efficiency measurement system. The system was designed to accommodate a range of rated heater capacities. For development purposes, three different DGFCHs $\left(21.9 \mathrm{~kW}\left(75,000 \mathrm{BTU} \mathrm{h}^{-1}\right), 29.3 \mathrm{~kW}\left(100,000 \mathrm{BTU} \mathrm{h}^{-1}\right), 73.3 \mathrm{~kW}\left(250,000 \mathrm{BTU} \mathrm{h}^{-1}\right)\right)$ were tested, procedural differences for each capacity are discussed in the testing procedure section. All tests were performed in the Air Dispersion Laboratory (ADL). See [6] for specifics of the laboratory.

\subsection{Instrumentation}

A Data Acquisition and Control (DAQC) system was developed to measure all necessary parameters to calculate the thermal efficiency of a DGFCH (analytical analysis to be discussed in a later section). The DAQC system consisted of two sub-systems, one to measure the input energy into the DGFCHs and one to measure the output enthalpy of the output air.

The instrumentation system for measuring input energy consisted of sensors to measure the propane input and electrical energy used by the DGFCH. Two different set-ups were created for propane input measurement. For DGFCHs rated $<30 \mathrm{~kW}$, a mass flow system was used, and for DGFCHs rated $>30 \mathrm{~kW}$, a volumetric device was used. This was performed as the minimum flow rates for traditional style diaphragm gas flowmeters exhibit high uncertainty for $30 \mathrm{~kW}$ rated heaters and below based on manufacturer specifications due to the extremely low flowrates. The mass flow system was not used for all heaters as the uncertainty in propane input was high, discussed in later section. 
The mass flow system consisted of a $45.4 \mathrm{~kg}(100 \mathrm{lb})$ propane tank placed on a steel platform with a single-point $150 \mathrm{~kg}$ load cell with a $2 \mathrm{mV} \mathrm{V}^{-1}$ linear response signal (see Table 1 for specifications). The load cell signal was conditioned by a programmable-gain instrumentation amplifier (see Table 1 for specifications). A dual-stage regulator rated for $58.6 \mathrm{~kW}$ at $2.74 \mathrm{kPa}$ was used (see Table 1 for specifications) with a $7.9 \mathrm{~mm}$ diameter flexible hose to connect the gas supply to the heater connection manifold.

Table 1. Energy input instruments used in the study in order as described in the text. FS = Full Scale.

\begin{tabular}{|c|c|c|c|c|}
\hline $\begin{array}{l}\text { Input Energy } \\
\text { Instrumentation }\end{array}$ & Manufacturer's Rating & $\begin{array}{l}\text { Manufacturer's } \\
\text { Accuracy }\end{array}$ & Model & Manufacturer \\
\hline Propane mass & $150.0 \mathrm{~kg}$ & $2.0 \times 10^{-2} \% \mathrm{FS}$ & RLPWM12-150 kg & $\begin{array}{c}\text { Rice Lake Weighing Systems, Rice } \\
\text { Lake, WI, USA }\end{array}$ \\
\hline $\begin{array}{l}\text { Programmable amplifier } \\
\text { Propane regulator }\end{array}$ & $\begin{array}{c}\text { NA } \\
58.6 \mathrm{~kW}\end{array}$ & $\begin{array}{l}\text { NA } \\
\text { NA }\end{array}$ & $\begin{array}{c}\text { PGA } 204 \\
\text { Model } 9059398\end{array}$ & $\begin{array}{l}\text { Texas Instruments, Dallas, TX, USA } \\
\text { Char-Broil, Columbus, GA, USA }\end{array}$ \\
\hline Propane flowmeter & $\underset{2.8 \mathrm{E}-4 \mathrm{~m}^{3} \mathrm{~s}^{-1}}{\text { Minimum flow }}=$ & $4.0 \times 10^{-1} \mathrm{~s}^{-1} \mathrm{~m}^{3}$ & Model PGM-150 & $\begin{array}{c}\text { EKM Metering, Santa Barbra, CA, } \\
\text { USA }\end{array}$ \\
\hline Propane temperature & -40.0 to $150.0{ }^{\circ} \mathrm{C}$ & $\pm 0.22{ }^{\circ} \mathrm{C}$ & $\begin{array}{c}\text { Model } \\
\text { TE-IBN-D044-14 }\end{array}$ & $\begin{array}{c}\text { Dwyer Instruments, Inc., Michigan } \\
\text { City, IN, USA }\end{array}$ \\
\hline Propane pressure & 0.0 to $103.4 \mathrm{kPa}$ & $1.0 \%$ FS & Model 628 & $\begin{array}{c}\text { Dwyer Instruments, Inc., Michigan } \\
\text { City, IN, USA }\end{array}$ \\
\hline Precision resistor & $1 \mathrm{k} \Omega$ & $\begin{array}{l} \pm 5.0 \times 10^{-2 \%} \\
\text { FS }\end{array}$ & Model 1k Tick & $\begin{array}{c}\text { Labjack Corporation, Lakewood, CO, } \\
\text { USA }\end{array}$ \\
\hline Electrical power meter & Max $3000 \mathrm{~A}$ at $830 \mathrm{~V}$ AC & $\pm 0.7 \%$ of $\mathrm{W}$ & Model 1735 & Fluke, Everett, WA, USA \\
\hline
\end{tabular}

The gas flowmeter (see Table 1 for specifications) was connected to the propane utility supply (two $3.79 \mathrm{~m}^{3}$ propane tanks with a line pressure of $2.74 \mathrm{kPa}$ ) using a $12.7 \mathrm{~mm}$ diameter flexible hose. The flowmeter's output was connected to the heater connection manifold with a $12.7 \mathrm{~mm}$ Internal Diameter (ID) flexible hose. Flowrate was determined by dividing the difference between the recorded initial and final positions of the dial on the flowmeter by the duration of the test.

The heater connection manifold consisted of a sediment trap (following manufacturer's recommendation) and two taps that contained a silvered PT100 Resistance Temperature Detector (RTD; see Table 1 for specifications) and a pressure transducer (see Table 1 for specifications) to monitor supply propane temperature and pressure, respectively. A precision resistor (see Table 1 for specifications) was used to create a voltage divider circuit to condition the RTD output signal with a supply voltage of 2.5 Volt DC (VDC) and the 4 to $20 \mathrm{~mA}$ signal from the pressure transducer. The RTD temperature was determined using the alpha equation (Equations (1) and (2)) for RTDs, with alpha determined using the resistance at $0{ }^{\circ} \mathrm{C}$ and $100{ }^{\circ} \mathrm{C}$. Heater electrical power consumption was measured using a portable power meter (see Table 1 for specifications).

$$
T_{i}=\frac{\left(\frac{R_{T}}{R_{0}}-1\right)}{\alpha}
$$

where

$T_{i}=$ temperature $\left({ }^{\circ} \mathrm{C}\right)$; where $i$ is RTD, propane, or exiting air

$R_{T}=$ RTD resistance at $T_{i}(\Omega)$ see Equation (2)

$R_{0}=$ RTD resistance at $0{ }^{\circ} \mathrm{C}(100 \Omega)$

$\alpha=$ temperature coefficient of resistance $\left(3.851 \mathrm{E}-4 \Omega^{\circ} \mathrm{C}^{-1}\right)$

$$
R_{T}=R_{d 1} *\left(\frac{V_{s}}{V_{\text {out }}}-1\right)
$$

where

$R_{d 1}=$ resistance of voltage divider resistor $(1 \mathrm{k} \Omega)$

$V_{S}=$ supply voltage (2.5 VDC)

$V_{\text {out }}=$ analog voltage output measured by DAQC board (VDC) 
Heater combustion exhaust measurement system consisted of a $0.2 \mathrm{~m}$ diameter, $2.44 \mathrm{~m}$ long round, galvanized steel duct that contained a PT100 RTD and a velocity pressure pitot tube (Figures 1 and 2, Tables 2 and 3). The same conditioning circuit and temperature equations were used as previously discussed. The supply end of the duct featured a flange fitting that was sealed with foil tape and secured to the face of the heater around the exhaust outlet. For heaters with larger output openings, a reduction flare fitting, $0.3 \mathrm{~m}$ to $0.2 \mathrm{~m}$ diameter and $0.3 \mathrm{~m}$ in length, was included. All seams on the inside of the duct were sealed with mastic caulking, and the outside of the duct was sealed with foil tape. The duct was wrapped with $51 \mathrm{~mm}(2 \mathrm{in}$.) thick, foil-backed fiberglass insulation. Additional insulation was placed on the seams on the fiberglass insulation, and all seams were sealed with foil tape. Velocity pressure was measured using a multi-range, differential pressure transducer (see Table 3 for specifications).

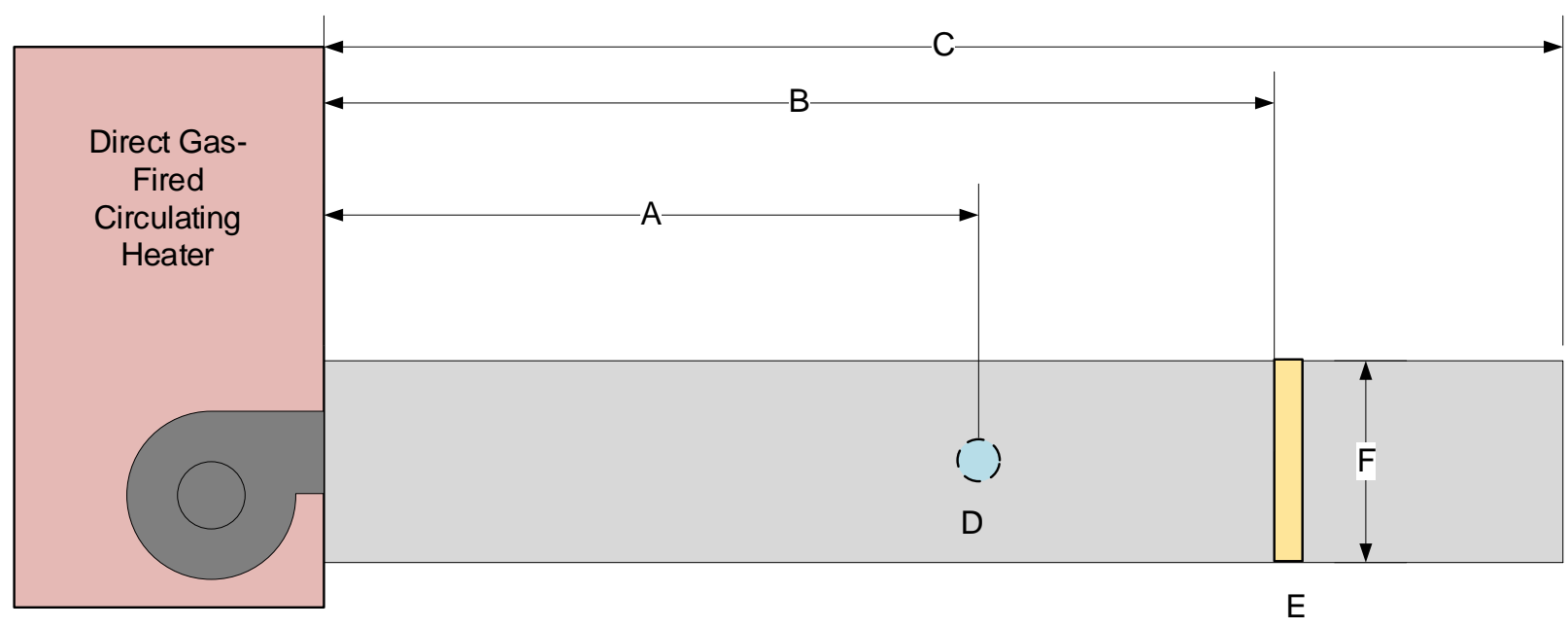

Figure 1. Test duct with locations of temperature measurement taps (D) and velocity pressure pitot tube (E). Measurements for the specific labels are in Table 1. Note diagram is not to scale.

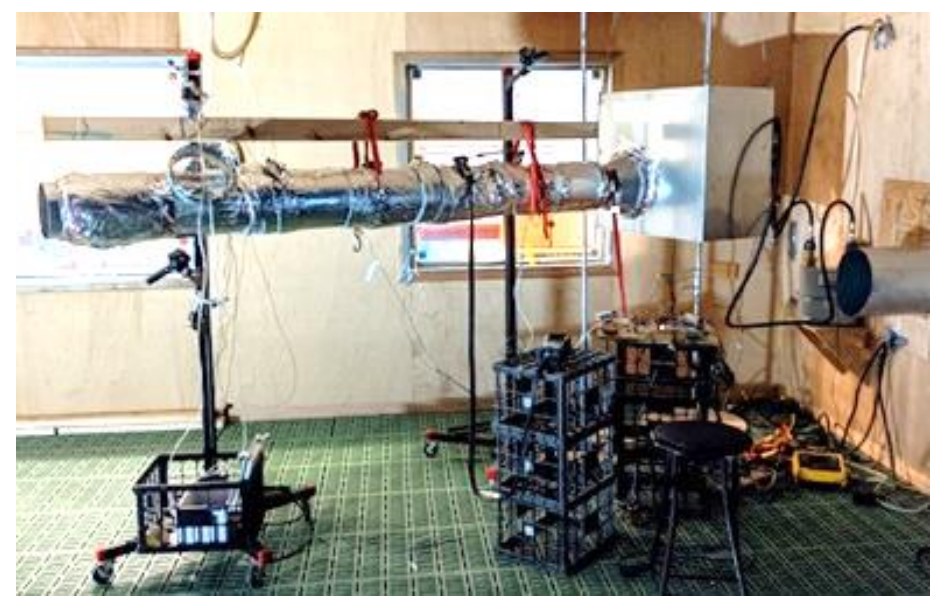

Figure 2. Test stand configuration and DAQC system in ADL for DGFCH test.

Table 2. Dimensions of the test duct in Figure 1.

\begin{tabular}{ccc}
\hline Label & Description & Measurement (m) \\
\hline A & Inlet to temperature tap & 1.3 \\
B & Inlet to velocity pressure pitot tube & 1.6 \\
C & Overall length of duct & 2.4 \\
F & Duct diameter & 0.2 \\
\hline
\end{tabular}


Table 3. Energy output instruments used in the study in order as described in the text.

\begin{tabular}{|c|c|c|c|c|}
\hline $\begin{array}{l}\text { Output Energy } \\
\text { Instrumentation }\end{array}$ & $\begin{array}{l}\text { Manufacturer's } \\
\text { Rating }\end{array}$ & $\begin{array}{c}\text { Manufacturer's } \\
\text { Accuracy }\end{array}$ & Model & Manufacturer \\
\hline Output air temperature & -40.0 to $150.0{ }^{\circ} \mathrm{C}$ & $\pm 0.2^{\circ} \mathrm{C}$ & Model TE-IBN-D044-14 & $\begin{array}{l}\text { Dwyer Instruments, Inc., } \\
\text { Michigan City, IN, USA }\end{array}$ \\
\hline $\begin{array}{l}\text { Output air velocity } \\
\text { pitot tube }\end{array}$ & 0.5 to $51 \mathrm{~m} \mathrm{~s}^{-1}$ & $\pm 2.0 \% \mathrm{FS}$ & Model FLST-C8 & $\begin{array}{l}\text { Dwyer Instruments, Inc., } \\
\text { Michigan City, IN, USA }\end{array}$ \\
\hline $\begin{array}{l}\text { Pitot tube pressure } \\
\text { transducer }\end{array}$ & 0.0 to $248.8 \mathrm{~Pa}$ & $\pm 1.0 \% \mathrm{FS}$ & Model 267 & $\begin{array}{l}\text { Setra Systems, Inc., } \\
\text { Boxborough, MA, USA }\end{array}$ \\
\hline $\begin{array}{l}\text { Incoming air } \\
\text { temperature }\end{array}$ & -40.0 to $105.0^{\circ} \mathrm{C}$ & $\pm 1.0 \%$ at $25^{\circ} \mathrm{C}$ & $\begin{array}{l}\text { Model TT05-10KC8-15- } \\
\text { T105-1500 }\end{array}$ & $\begin{array}{c}\text { TEWA Sensors, LLC, } \\
\text { Albuquerque, NM, USA }\end{array}$ \\
\hline Precision resistor & $10 \mathrm{k} \Omega$ & $\pm 5.0 \times 10^{-2} \% \mathrm{FS}$ & Model 10K Tick & $\begin{array}{l}\text { Labjack Corporation, } \\
\text { Lakewood, CO, USA }\end{array}$ \\
\hline $\begin{array}{l}\text { Incoming air } \\
\text { temperature and } \\
\text { relative humidity }\end{array}$ & $\begin{array}{c}-40.0 \text { to } 80.0^{\circ} \mathrm{C}, 0.0 \\
\text { to } 100.0 \% \mathrm{RH}\end{array}$ & $\pm 0.1^{\circ} \mathrm{C}, \pm 1.5 \% \mathrm{RH}$ & Model HMT120 & Vaisala, Helsinki, Finland \\
\hline
\end{tabular}

Heater supply air (room) Dry-Bulb Temperature (Tdb) was measured using a grouping of four plastic-coated thermistors (see Table 3 for specifications) installed $0.25 \mathrm{~m}$ below the intake of the heater on the side opposite of the Liquid Propane (LP) intake and burner manifold. The four thermistors were multiplexed (Model: CD4052BE, Texas Instruments, Dallas, TX, USA) and conditioned with a voltage divider circuit consisting of a precision resistor (see Table 3 for specifications). Temperature from the thermistors was calculated using the $\beta$ equation (Equation (3)) and then converted to Celsius for analysis. The thermistors were calibrated in a variable environment chamber (Series 7064-3140, Parameter Generation \& Control, Black Mountain, NC, USA) at three unique temperatures $\left(25^{\circ} \mathrm{C}\right.$, $35^{\circ} \mathrm{C}$, and $45^{\circ} \mathrm{C}$ ) using the exact same DAQC setup prior to testing. The calibration regression was developed by regressing the chamber temperature recoded from the control panel on the $\mathrm{x}$-axis and the average thermistor temperature on the $\mathrm{y}$-axis. The final calibration equation was determined by taking the inverse of the previous calibration equation [7].

$$
T_{T R i}=1 /\left[(1 / 298.15)+(1 / \beta) * \ln \left(\left(R_{d 10} *\left(V_{s 1} / V_{o u t 1}-1\right)\right) / R_{r e f}\right)\right]
$$

where

$T_{T R}=$ thermistor temperature $i(\mathrm{~K})$

$B=$ thermistor coefficient (3435)

$R_{d 10}=$ resistance of voltage divider resistor $(\Omega)$

$V_{s 1}=$ voltage supply (5.0 VDC)

$V_{\text {out } 1}=$ analog voltage output measured by DAQC (VDC)

$R_{r e f}=$ thermistor reference resistance at $25^{\circ} \mathrm{C}(\Omega)$

Supply air Tdb and Relative Humidity (RH) were measured in the same location using a portable hygrometer with a Liquid Crystal Display (LCD) screen (see Table 3 for specifications). The remote hygrometer was recorded manually at the start and end of each test.

All sensors, excluding the remote sensing unit, were recorded with a custom software interface (Visual Basic v19, Microsoft, Redmond, WA, USA). The software allowed for user-selectable sampling frequency and a calibration procedure to calibrate the load cell.

\subsection{Testing Procedure}

Data were collected on the three nominally rated DGFCHs $(21,29$, and $73 \mathrm{~kW})$ at the full rated output and half output setting. For the 21 and $29 \mathrm{~kW}$ rated heaters, three replicates of each output were measured. For the $73 \mathrm{~kW}$ heater, two replicates of each output were completed. This was due to issues with the test duct retaining residual heat 
between tests. Prior to test initiation, the load cell was verified with a $45.4 \mathrm{~kg}(100 \mathrm{lb})$ standard set of weights. During a test, the DAQC was configured to sample continuously at $1 \mathrm{~Hz}$. For DGFCH ratings $>18 \mathrm{~kW}$, the total sampling duration was $500 \mathrm{~s}$ with the DAQC system sampling at $1 \mathrm{~Hz}$. For DGFCH ratings $<18 \mathrm{~kW}$, the total sampling duration was $900 \mathrm{~s}$, with the DAQC sampling at $1 \mathrm{~Hz}$. The time duration was different for the heater and settings rated for $<18 \mathrm{~kW}$ based on the anticipated propane consumption to have a minimum change in the propane tank mass double the load cells accuracy. Electrical energy consumption was recorded from the power meter at 3 min into the test and assumed constant for the duration of the test. The three-minute mark was selected based on ANSI/ASHRAE Standard 103, considering steady-state combustion at three minutes [5]. Between performance tests, the ADL was ventilated for $60 \mathrm{~min}$ to maintain similar room temperatures at the start of each test.

\subsection{Thermal Efficiency Development}

The energy balance of a DGFCH is the balance of the energy input and output of the heater (Equation (4)). Output DGFCH energy can be defined as the sum of the combustion heat in the output airflow and the radiative and convective heat loss of the heater jacket (Equation (5)). For agriculture buildings, the main objective is to warm the occupied zones of the house. Thus, the goal of a DGFCH thermal efficiency is to quantify the efficiency of heating the output air (Equation (6); [5]).

$$
Q_{\text {out }}=Q_{\text {in }}
$$

where

$Q_{\text {out }}=$ energy output of a direct gas-fired circulating heater $(\mathrm{kW})$

$Q_{i n}=$ energy input (propane and electrical) of a direct gas-fired circulating heater $(\mathrm{kW})$

$$
Q_{o u t}=Q_{a}+Q_{j}
$$

where

$Q_{a}=$ energy output via air $(\mathrm{kW})$

$Q_{j}=$ energy output via heater jacket $(\mathrm{kW})$

$$
\hat{Q}_{\text {out }}=Q_{\text {in }} \times n_{\text {ss }}
$$

where

$\hat{Q}_{o u t}=$ measured energy output of heater output air (full or half load; $\mathrm{kW}$ )

$n_{s s}=$ steady-state sensible energy output efficiency (\%)

Energy input into a DGFCH can be quantified as the energy from the liquid propane plus the electrical energy (Equation (7)). Electrical energy is included as most of the DGFCH supply air is drawn in over the motor and electronic components for cooling purposes. For the 21 and $29 \mathrm{~kW}$ rated heaters, input propane was measured gravimetrically, while input propane for the $73 \mathrm{~kW}$ rated heater was measured volumetrically, with a temperature and pressure compensated gas meter.

$$
Q_{\text {in }}=\left(\dot{x}_{L P G} \times H H V_{\text {prop }}\right)+W_{\text {elec }}
$$

where

$\dot{x}_{L P G}=$ mass flow rate of propane to heater $\left(\mathrm{kg} \mathrm{s}^{-1}\right)$ or volume flow rate of propane $\left(\mathrm{m}^{3} \mathrm{~s}^{-1}\right)$

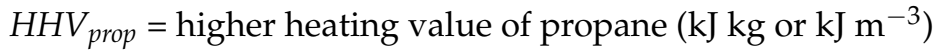

$W_{\text {elec }}=$ electrical energy consumption of heater $(\mathrm{kW})$

$$
\hat{Q}_{\text {out }}=\dot{m}_{a} \times\left(h_{\text {out }}-h_{\text {in }}\right)
$$

where 
$\dot{m}_{a}=$ mass flow rate of exhaust air from heater $\left(\mathrm{kg} \mathrm{s}^{-1}\right)$

$h_{\text {out }}=$ enthalpy of output air from heater $\left(\mathrm{kJ} \mathrm{kg}^{-1}\right)$

$h_{\text {in }}=$ enthalpy of oncoming air to heater $\left(\mathrm{kJ} \mathrm{kg}^{-1}\right)$

$$
\dot{m}_{a}=\vec{V} \times\left(\pi r^{2}\right) \times \rho
$$

where

$\vec{V}=$ fluid velocity $\left(\mathrm{m} \mathrm{s}^{-1}\right)$

$r=$ radius of the duct $(0.10 \mathrm{~m})$

$\rho=$ density of the air exiting heater $\left(\mathrm{kg} \mathrm{m}^{-3}\right)$

$$
\vec{V}=\sqrt{\frac{2 \delta p}{\rho}}
$$

where

$\delta p=$ velocity pressure measurement $(\mathrm{Pa})$

The output energy was quantified by the enthalpy change of the air moving through the heater (Equation (8)). The mass flow of the DGFCH exhaust air was calculated using the density measurements and the pitot tube measurement (Equations (9) and (10)). The specific volume and enthalpy were calculated using the humidity ratio of the starting room conditions $[1,8]$

By combining the input energy (Equation (4)) and the quantified energy output (Equation (5)), the steady-state thermal efficiency can be solved for the DGFCH (Equations (11) and (12)). The thermal efficiency equation is similar in nature to efficiency equations used to evaluate solar air heaters $[9,10]$

$$
\begin{aligned}
& \dot{m}_{a} \times\left(h_{\text {out }}-h_{\text {in }}\right)=\left(\left(\dot{x}_{\text {prop }} \times H H V_{\text {prop }}\right)+W_{\text {elec }}\right) \times n_{\text {ss }} \\
& n_{\text {ss }}=\left(\dot{m}_{a} \times\left(h_{\text {out }}-h_{\text {in }}\right)\right) \div\left(\left(\dot{x}_{\text {prop }} \times H H V_{\text {prop }}\right)+W_{\text {elec }}\right)
\end{aligned}
$$

\subsection{Thermal Efficiency Calculations and Analysis}

From each replicate, the mean of six random sub-samples of $30 \mathrm{~s}(n=30$ per subsample) of consecutive data was used to calculate the steady-state thermal efficiency (Equation (12)). A moving average of five data points was used to reduce fluctuations in the output air temperature. This processing step was justified due to the random error caused by turbulence and non-constant combustion of the heater. The mass flow rate of the propane was calculated by determining the weight change of the propane cylinder divided by the experiment duration. For DGFCH's rated $>18 \mathrm{~kW}$, a $4 \mathrm{~s}$ average before the heater solenoid was opened and after the test was used to determine the pre- and post-weight. For DGFCH's rated $<18 \mathrm{~kW}$, a $3 \mathrm{~s}$ average was used. The averaging of the cylinder weight was necessary to account for variation in the weight caused by vibration of the cylinder due to propane flow.

A sensitivity analysis of the steady-state thermal efficiency was performed with respect to the Higher Heating Value (HHV) of propane. Four sources of the HHV were used in the analysis due to the slight differences among sources (Table 4).

Table 4. Higher Heating Value (HHV) values from different sources used in the sensitivity analysis of the thermal efficiency equation.

\begin{tabular}{ccc}
\hline Source & HHV $\left(\mathbf{k J ~ k g}^{\mathbf{- 1}}\right)$ & References \\
\hline A & 50,009 & {$[5]$} \\
B & 50,411 & {$[8]$} \\
C & 50,656 & {$[11]$} \\
D & 50,129 & {$[12]$} \\
\hline
\end{tabular}




\subsection{Uncertainty Analysis}

The final standard uncertainty of the thermal efficiency $\left(\Delta n_{s s}\right)$ was calculated from the standard uncertainty obtained from all key measurement inputs propagated through (Equation (13) through Equation (20), Figure 3).

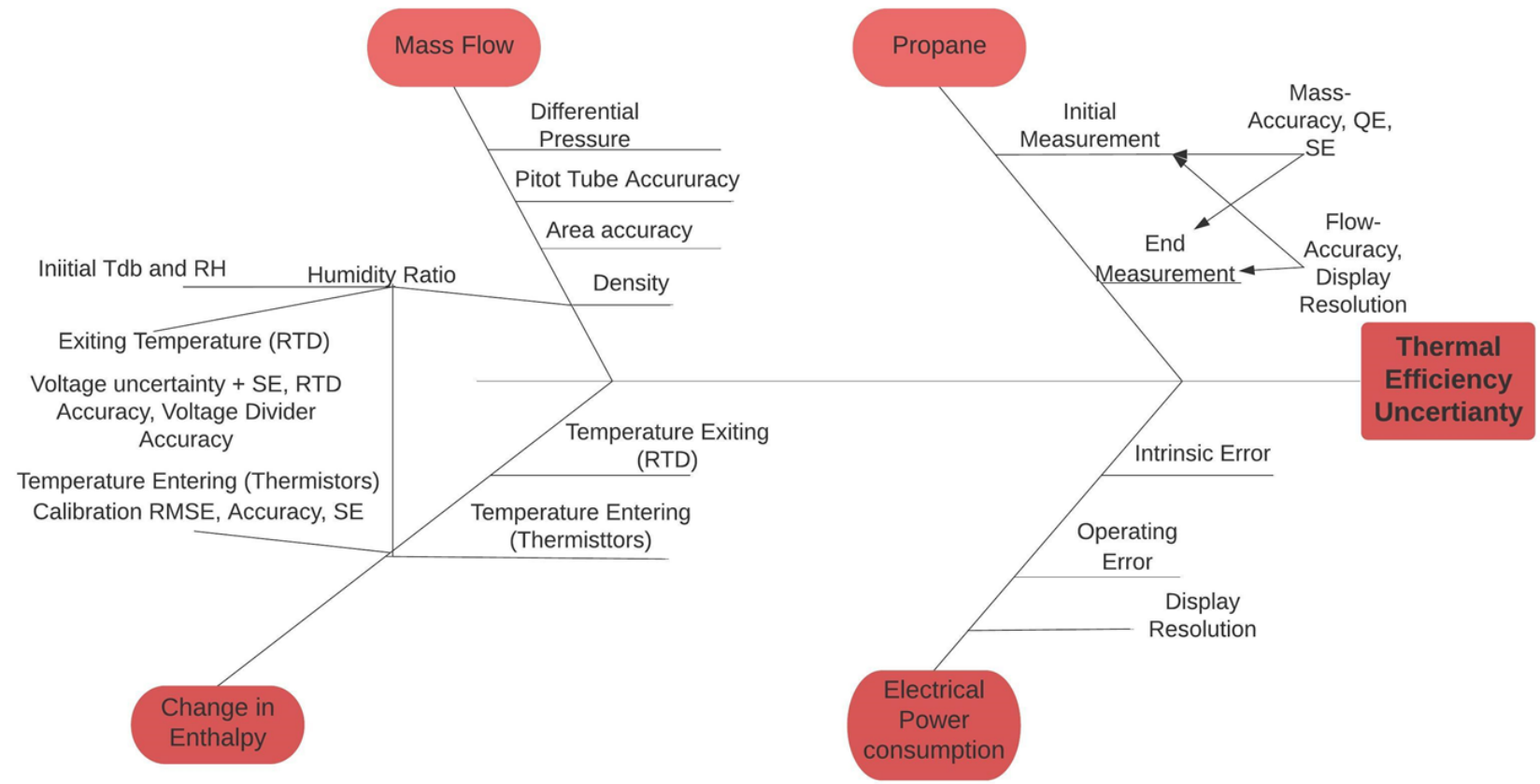

Figure 3. Fishbone diagram of the final standard uncertainty in the thermal efficiency calculation. Each line represents the integration of a measurement and its respective uncertainty into a standard uncertainty calculation.

A zeroth-ordered uncertainty budget was created for each measured input: voltage measurement for exiting air temperature $\left(T_{e x} ;\right.$ Table 5$)$, a Differential Pressure Transducer (DPT; Table 6), dry-bulb temperature, and relative humidity for humidity ratio calculation (Tdb and RH; Table 7), propane flow for mass and volumetric ( $\dot{x}$; Table 8$)$, and electrical energy consumption $\left(W_{\text {elec }} ;\right.$ Table 9$)$ and included the manufacturer's accuracy and long-term stability, quantization error from the 14-bit Analog-to-Digital Converter (ADC), and the Standard Error (SE) from the experimental data (SE was removed from the budget as it changes with each experiment; [13]).

Table 5. Uncertainty budget analog voltage measurement by DAQC board for RTD measurement.

\begin{tabular}{ccccc}
\hline & Value (VDC) & Probability Distribution & Divisor & Standard Uncertainty (Pa) \\
\hline Accuracy $^{[\mathrm{a}]}{ }^{\left[{ }^{[b]}\right.}$ & $3.7 \times 10^{-3}$ & Rectangular & $\sqrt{3}$ & $2.1 \times 10^{-3}$ \\
Quantization error $^{2}$ & $3.1 \times 10^{-4}$ & Rectangular & $\sqrt{3}$ & $1.8 \times 10^{-4}$ \\
& Combined standard sensor uncertainty, $\Delta$ VDC & & $2.1 \times 10^{-3}$ \\
\hline
\end{tabular}

${ }^{[\mathrm{a}]} \pm 0.5$ Manufacturer's stated accuracy with \pm 5 . VDC input range. ${ }^{[\mathrm{b}]} \pm 0.5$ ADC resolution $=14$-bit ADC resolution, \pm 5 VDC reference range $=3.1 \mathrm{E}-4 \mathrm{~V} \mathrm{BL}^{-1}$. BL $=$ Binary Level.

Table 6. Uncertainty budget for differential pressure transducer.

\begin{tabular}{ccccc}
\hline Source & Value (Pa) & Probability Distribution & Divisor & Standard Uncertainty (Pa) \\
\hline Accuracy RSS [a] & 2.5 & Rectangular & $\sqrt{3}$ & 1.4 \\
Long-term stability & 5.0 & Rectangular & $\sqrt{3}$ & 2.9 \\
Quantization error ${ }^{[b]}$ & $3.2 \times 10^{-2}$ & Rectangular & $\sqrt{3}$ & $1.8 \times 10^{-2}$ \\
& Combined standard sensor uncertainty, $\Delta \delta p$ & & 3.2 \\
\hline
\end{tabular}

${ }^{\text {[a] }}$ Root sum square (at constant $\mathrm{t}_{\mathrm{db}}$ ), $\pm 1.0 \%$ full scale $(\delta p 1) 0$ to $248.8 \mathrm{~Pa}^{\mathrm{bb}} \pm 0.5$ sensor resolution $=$ (14-bit ADC resolution, \pm 10 VDC reference range $\left.=6.1 \mathrm{E}-4 \mathrm{~V} \mathrm{BL}^{-1}\right)$ (sensor sensitivity $)^{-1}$. 
Table 7. Uncertainty budget for temperature and relative humidity sensor used to calculate humidity ratio.

\begin{tabular}{ccccc}
\hline Source & Value $\left({ }^{\circ} \mathbf{C}, \mathbf{\%} \mathbf{R H}\right)$ & Probability Distribution & Divisor & Standard Uncertainty $\left({ }^{\circ} \mathbf{C}, \% \mathbf{~ R H}\right)$ \\
\hline Accuracy RSS [a] & $0.1,1.5$ & Rectangular & $\sqrt{3}$ & $5.7 \times 10^{-2}, 8.7 \times 10^{-1}$ \\
Long-term stability & $\mathrm{N} / \mathrm{A}[\mathrm{c}], 1.0$ & Rectangular & $\sqrt{3}$ & $\mathrm{~N} / \mathrm{A}\left[\mathrm{c]}, 5.7 \times 10^{-1}\right.$ \\
Display Resolution $^{[\mathrm{b}]}$ & $\begin{array}{c}5.0 \times 10^{-3}, 5.0 \times 10^{-3} \\
\text { Combined standard sensor uncertainty, } \Delta t_{d b}, \Delta r h\end{array}$ & $\sqrt{3}$ & $2.9 \times 10^{-3}, 2.9 \times 10^{-3}$ \\
& & Rectangular & $5.7 \times 10^{-2}, 1.0$ \\
\hline
\end{tabular}

${ }^{[\mathrm{a}]}$ Manufacturer stated accuracy; ${ }^{[\mathrm{b}]} \pm 0.5$ smallest display value $=0.01$; ${ }^{[c]}$ long-term stability is included in accuracy term from manufacturer specifications.

Table 8. Uncertainty budget for propane for both mass and flow basis.

\begin{tabular}{|c|c|c|c|c|}
\hline Source & Value $\left(\mathrm{kg}, \mathrm{m}^{3} \mathrm{~s}^{-1}\right)$ & Probability Distribution & Divisor & Standard Uncertainty $\left(\mathrm{kg}, \mathrm{m}^{3} \mathrm{~s}^{-1}\right)$ \\
\hline Accuracy RSS [a] & $1.0 \times 10^{-2}, 4.4 \times 10^{-4}$ & Rectangular & $\sqrt{3}$ & $5.7 \times 10^{-2}, 2.6 \times 10^{-4}$ \\
\hline Long-term stability & $\mathrm{N} / \mathrm{A}^{[\mathrm{c}]}, \mathrm{N} / \mathrm{A}^{[\mathrm{c}]}$ & Rectangular & $\sqrt{3}$ & $\mathrm{~N} / \mathrm{A}^{[\mathrm{c}]}, \mathrm{N} / \mathrm{A}^{[\mathrm{c}]}$ \\
\hline Display Resolution $[\mathrm{b}]$ & $\mathrm{N} / \mathrm{A}, 1.4 \times 10^{-3}$ & Rectangular & $\sqrt{3}$ & $\mathrm{NA}, 2.5 \times 10^{-3}$ \\
\hline Quantization Error $[\mathrm{d}]$ & $6.1 \times 10^{-3}, \mathrm{~N} / \mathrm{A}$ & Rectangular & $\sqrt{3}$ & $3.5 \times 10^{-3}, \mathrm{~N} / \mathrm{A}$ \\
\hline \multicolumn{4}{|c|}{ Combined standard sensor uncertainty, $\Delta \dot{x}_{m}, \Delta \dot{x}_{f}$} & $5.8 \times 10^{-2}, 2.4 \times 10^{-3}$ \\
\hline
\end{tabular}

${ }^{[\mathrm{a}]}$ Manufacturer stated accuracy; ${ }^{[\mathrm{b}]} \pm 0.5$ smallest display value $=0.01 ;{ }^{[c]}$ long-term stability is included in accuracy term from manufacturer specifications; $^{[\mathrm{d}]} \pm 0.5$ sensor resolution $=\left(\right.$ 14-bit $\mathrm{ADC}$ resolution, $1 \mathrm{VDC}$ reference range $\left.=1.2 \mathrm{E}-4 \mathrm{~V} \mathrm{BL}^{-1}\right)(\text { sensor sensitivity })^{-1}$.

Table 9. Uncertainty budget for electrical energy consumption of the heater.

\begin{tabular}{ccccc}
\hline Source & Value (W) & Probability Distribution & Divisor & Standard Uncertainty (W) \\
\hline Intrinsic error & 241.5 & Rectangular & $\sqrt{3}$ & 139.4 \\
Operating error $^{[a]}$ & 517.5 & Rectangular & $\sqrt{3}$ & 298.8 \\
Display Resolution $^{[a}$ & 50 & Rectangular & $\sqrt{3}$ & 28.9 \\
& & & & 331.0 \\
\hline
\end{tabular}

[a] \pm 0.5 smallest display value $=50$.

The uncertainty budget for the Tdb and RH includes a display resolution component as it was manually recorded (Table 7). The propane volumetric measurement also had a display resolution component from the dial on the meter display from manually recording measurements.

The standard uncertainty associated with the area of the duct was determined by propagating the standard uncertainty of the duct radius $\left(\Delta \mathrm{r}=2.70 \times 10^{-3} \mathrm{~m}\right.$, one-half the reading resolution set by the manufacturer) through the area equation of a circle resulting in a standard uncertainty of the area $\Delta \mathrm{a}=3.39 \times 10^{-3} \mathrm{~m}^{2}$.

$$
\Delta V D C_{i}^{2}=\left(\frac{\Delta V D C}{n}\right)^{2}+S E^{2}
$$

where

$\triangle V D C_{i}=$ combined standard uncertainty in analog voltage measurement $\left(T_{e x} \mathrm{VDC}\right)$ $S E=$ standard error of the voltage measurement (VDC)

$$
\Delta T_{e x}^{2}=\left(\frac{\partial T_{e x}}{\partial V D C} \Delta V D C_{i}\right)^{2}+\left(\frac{\partial T_{e x}}{\partial R_{d 1}} \Delta R_{d 1}\right)^{2}+\left(\frac{\partial T_{e x}}{\partial R_{r e f}} \Delta R_{r e f}\right)^{2}+R M S E^{2}
$$

where

$\Delta T_{\text {ent }}=$ combined standard uncertainty in entering air temperature $\left({ }^{\circ} \mathrm{C}\right)$

$\Delta R_{d 1}=1 \mathrm{k} \Omega$ resistor in divider circuit $( \pm 0.05 \% ; \Omega$; rectangular distribution)

$\Delta R_{\text {ref }}=100 \Omega$ at $0{ }^{\circ} \mathrm{C}( \pm 0.12 \% ; \Omega$; rectangular distribution $)$ 
$R M S E=$ root mean square error from nonlinear regression $\left({ }^{\circ} \mathrm{C}\right)$

The standard uncertainty of the entering temperature measured by the thermistor did not include propagation of uncertainty through (Equation (3)) as the DAQC system was identical in both calibration and testing. Thus, it was assumed that the RMSE of the calibration encompasses the uncertainty associated with the measurements propagated through the equation.

$$
\Delta T_{\text {ent }}^{2}=A C C^{2}+R M S E^{2}+S E^{2}
$$

where

$\Delta T_{\text {ent }}=$ combined standard uncertainty in entering air temperature $\left({ }^{\circ} \mathrm{C}\right)$

$A C C=$ manufacturer's accuracy $\left( \pm 0.2^{\circ} \mathrm{C}\right.$; rectangular distribution $)$

$R M S E=$ root mean square error from linear calibration regression $\left({ }^{\circ} \mathrm{C}\right)$

$S E=$ standard error of the mean $\left({ }^{\circ} \mathrm{C}\right)$

$$
\Delta W^{2}=\left(\frac{\partial W}{\partial t_{d b}} \Delta t_{d b}\right)^{2}+\left(\frac{\partial \rho}{\partial r h} \Delta r h\right)^{2}
$$

where

$\Delta W=$ combined standard uncertainty in humidity ratio $\left(\mathrm{kg}_{\mathrm{H} 2 \mathrm{O}} \mathrm{kg}_{\mathrm{da}}{ }^{-1}\right)$

$$
\Delta \rho^{2}=\left(\frac{\partial \rho}{\partial t_{e x}} \Delta t_{e x}\right)^{2}+\left(\frac{\partial \rho}{\partial W} \Delta W\right)^{2}
$$

where

$\Delta \rho=$ combined standard uncertainty in moist air density $\left(\mathrm{kg} \mathrm{m}^{-3}\right)$

The standard uncertainty in the mass flow (Equation (18)) was determined from the propagation of the velocity pressure uncertainty, density uncertainty, area uncertainty, and accuracy of the pitot tube system.

$$
\Delta \dot{m} a^{2}=\left(\frac{\partial \dot{m} a}{\partial d p} \Delta d p\right)^{2}+\left(\frac{\partial \dot{m} a}{\partial \rho} \Delta \rho\right)^{2}+\left(\frac{\partial \dot{m} a}{\partial a} \Delta a\right)^{2}+A C C_{v}^{2}
$$

where

$\Delta \dot{m a}=$ combined standard uncertainty in mass flow moist air $\left(\mathrm{kg} \mathrm{s}^{-1}\right)$

$A C C_{v}=$ accuracy of the velocity measurement $(1.0 \%,[5])$

$$
\Delta h_{\text {ex }- \text { ent }}{ }^{2}=\left(\frac{\partial h_{\text {out }- \text { in }}}{\partial W} \Delta W\right)^{2}+\left(\frac{\partial h_{\text {out }- \text { in }}}{\partial T_{\text {ent }}} \Delta T_{\text {ent }}\right)^{2}+\left(\frac{\partial h_{\text {out-in }}}{\partial T_{\text {ex }}} \Delta T_{\text {ex }}\right)^{2}
$$

where

$\Delta h_{\text {out-in }}=$ combined standard uncertainty in change in enthalpy $\left(\mathrm{kJ} \mathrm{kg}^{-1}\right)$

The standard uncertainty of $\dot{x}_{L P G}$ included in (Equation (20)) included the SE term for the initial and final measurement from the gravimetric system as a multi-second average was used. It was assumed that there was no uncertainty in the run time of each test factored into $\dot{x}_{L P G}$.

$\Delta n_{s s}{ }^{2}=\left(\frac{\partial n_{s s}}{\partial \dot{m} a} \Delta \dot{m a}\right)^{2}+\left(\frac{\partial n_{s s}}{\partial h_{\text {ex }- \text { ent }}} \Delta h_{\text {ex }- \text { ent }}\right)^{2}+\left(\frac{\partial n_{s s}}{\partial \dot{x}} \Delta \dot{x}_{L P G}\right)^{2}+\left(\frac{\partial n_{s S}}{\partial W_{\text {elec }}} \Delta W_{\text {elec }}\right)^{2}$

where

$\Delta n_{s S}=$ combined standard uncertainty in thermal efficiency (\%)

The combined standard uncertainty was calculated using the data from each replicate of the heater model and output setting. Thus, for each replicate and output, a standard 
deviation was calculated for the uncertainty due to variations in measurements between each replicate.

\subsection{Economics of Heater Efficiency}

Economic implications of heating agricultural buildings were assessed by modifying the degree-day heating method (Equation (21); [3]). The method is simpler than other heating cost methods that use binned ambient weather data, with the consequence of overestimating the heating season costs. The efficiency represents the Annual Fuel Energy Use Efficiency (AFEUE). The AFEUE is based on the ASHRAE standard 103 [5]. For DGFCH without a pilot light, the AFEUE is the same as the steady-state thermal efficiency. For a DGFCH with a pilot light, the calculation of AFEUE considers the proportion of time with the pilot light on and its efficiency over the duration of the heating season.

$$
E=C_{D} \times\left[\left(H_{L} \times D \times S\right) \div\left(\Delta t \times n_{s s / A E U} \times H H V_{\text {prop }}\right)\right]
$$

where

$E=$ propane usage per season $(\mathrm{kg})$

$C_{D}=$ correction factor for degree-days (0.6)

$H_{L}=$ design heating load at minimum ventilation $(\mathrm{kW})$

$D=$ degree-days $\left({ }^{\circ} \mathrm{C}\right.$ day $)$

$S=$ seconds per day $\left(86,400 \mathrm{~s} \mathrm{~d}^{-1}\right)$

$\Delta t=$ design temperature difference, inside/outside $\left({ }^{\circ} \mathrm{C}\right)$

$H H V_{\text {prop }}=$ higher heating value for propane $\left(\mathrm{kJ} \mathrm{kg}^{-1}\right)$

The calculation of the heating load for a building (heat gain/heat loss) was developed to account for the wide variety of building specifications (Equation (22)). This was performed by accounting for the heat gain on the basis of floor area. The heating load is to be calculated at the wintertime $99 \%$ design temperature for the given location.

$$
H L=\left[(U A \times \Delta T)+\left(\dot{V}_{b} \div v \times C_{p} \times \Delta T\right)\right]+\left[q_{g} \times A_{f}\right]
$$

where

$U A=$ overall building heat loss coefficient $\left(\mathrm{W}^{\circ} \mathrm{C}^{-1}\right)$

$\dot{V}_{b}=$ minimum ventilation rate $\left(\mathrm{m}^{3} \mathrm{~s}^{-1}\right)$

$v=$ specific volume of air/water mixture $\left(\mathrm{kg} \mathrm{m}^{-3}\right)$

$C_{p}=$ specific heat of air $\left(\mathrm{J} \mathrm{kg}^{-1}\right)$

$Q_{g}=$ heat production per unit of floor area $\left(\mathrm{W} \mathrm{m}^{-2}\right)$

$A_{f}=$ floor area of building $\left(\mathrm{m}^{2}\right)$

A sensitivity analysis of the energy usage (Equation (21)) was performed based on recommended thermal resistance ( $\mathrm{R}$ values) for various building components, internal design temperature, two different minimum ventilation rates, and heater efficiency. This analysis used a high heat gain per unit floor area of $1.6 \mathrm{~W} \mathrm{~m}^{-2}$. It was assumed that the outside design temperature was $-29^{\circ} \mathrm{C}(99 \%$ heating value for Minnesota; [8]). For this economic analysis, the building size was $45.7 \mathrm{~m}(\mathrm{~L}), 15.2 \mathrm{~m}(\mathrm{~W})$ with a $2.5 \mathrm{~m}$ ceiling $(150 \mathrm{ft} \mathrm{L}, 50 \mathrm{ft} \mathrm{W}$ with $8 \mathrm{ft}$ ceiling). The building's thermal analysis assumed no windows and doors and did not include any perimeter or floor heat loss. The $\mathrm{R}$ values, internal building temperature, and minimum ventilation rates (Table 10). For the analysis of the first three components (level of insulation, design internal $\mathrm{Tdb}$, and minimum ventilation rate), the heater efficiency was $99 \%$, and the cost of propane was assumed at USD $\$ 0.53 \mathrm{~kg}^{-1}\left(\$ 1\right.$ gallon $\left.^{-1}\right)$. 
Table 10. Sensitivity analysis inputs for $\mathrm{R}$ values, internal building temperature, and minimum ventilation rate. Recommended levels of insulation for homes based on climate [3].

\begin{tabular}{|c|c|c|}
\hline Level of Insulation & Wall $\left(\mathrm{R} \mathrm{m}^{2}{ }^{\circ} \mathrm{C} \mathrm{W}^{-1}\right)$ & Ceiling $\left(\mathrm{R} \mathrm{m}^{2}{ }^{\circ} \mathrm{C} \mathrm{W}^{-1}\right)$ \\
\hline $\mathrm{UA}_{\text {low }}$ & 2.1 & 3.5 \\
\hline $\mathrm{UA}_{\text {medium }}$ & 2.5 & 4.4 \\
\hline $\mathrm{UA}_{\text {high }}$ & 3.5 & 5.8 \\
\hline $\mathrm{UA}_{\text {ultra-high }}$ & 3.5 & 6.7 \\
\hline \multicolumn{3}{|c|}{ Design internal temperature } \\
\hline $\mathrm{Ti}_{\text {high }}=28^{\circ} \mathrm{C}$ & $\mathrm{Ti}_{\text {medium }}=25^{\circ} \mathrm{C}$ & $\mathrm{Ti}_{\text {low }}=20^{\circ} \mathrm{C}$ \\
\hline \multicolumn{3}{|l|}{ Minimum ventilation rate } \\
\hline & $\mathrm{V}_{\text {high }}=6 \mathrm{ACH}^{[\mathrm{a}]}$ & $\mathrm{V}_{\text {low }}=3 \mathrm{ACH}^{[\mathrm{a}]}$ \\
\hline
\end{tabular}

[a] $\mathrm{ACH}=$ air changes per hour.

\section{Results and Discussion}

\subsection{Thermal Efficiency}

The average values of the operational parameters and results for the three DGFCHs tested at each output performed as expected (Table 11). The procedures developed were capable of detecting the relatively small differences in input and output energy, although the $73 \mathrm{~kW}$ did not reach rated operation. The time to steady-state assumed from ASHRAE 103 was represented in the results of this study (Figure 4), with all heaters and replicates showing similar trends in temperature change over time. Future tests should involve a high accuracy $\mathrm{CO}$ and $\mathrm{O}_{2}$ sensor to verify the thermal efficiency through stoichiometry (indirect combustion test). A unique trend was noted in the comparison of the half and full output thermal efficiencies. Heater models A and B exhibited higher thermal efficiencies at full output, while heater model $\mathrm{C}$ exhibited a higher thermal efficiency at half output. The thermal efficiency of over $100 \%$ is related to the system's uncertainty, discussed in the next section. The general trend of efficiency increasing with heater output could be influenced by the test stand gaining heat during the test and affecting measurements. This was the reason behind two replicates with heater model $\mathrm{C}$. The heater models used in the study had limited thermal efficiency values reported, model A had no reported values, and models B and C reported $99.99 \%$ thermal efficiency. The reported thermal efficiencies in this study are higher than what is assumed for DGFCH in buildings $80 \%$, with high humidity and low ventilation [4]. However, it was not within the scope of this study to evaluate the heaters under such conditions that are believed to drastically reduce the performance of these heaters in buildings. The thermal efficiency of the DGFCH used in this study is significantly higher $(>90 \%)$ compared to the thermal efficiency of common gas-fired residential units (63\% to $44 \%$; [13]). This drastic difference is mainly contributed to the difference in the heaters as the residential heaters.

Table 11. Average (standard deviation) of test conditions and measured performance values for all three DGFCH models and outputs.

\begin{tabular}{|c|c|c|c|c|c|c|}
\hline $\begin{array}{c}\text { Measured } \\
\text { Input }^{\text {[a] }}(\mathbf{k W})\end{array}$ & $\begin{array}{l}\text { Heater } \\
\text { Model }\end{array}$ & $\begin{array}{c}\text { Manifold } \\
\text { Pressure (kPa) }\end{array}$ & $\begin{array}{c}\text { Output Air } \\
\text { Temperature }\left({ }^{\circ} \mathrm{C}\right)\end{array}$ & $\begin{array}{l}\text { Enthalpy Gain } \\
\left(\mathrm{kJ} \mathrm{kg} \mathrm{da} \mathrm{da}^{-1}\right)\end{array}$ & $\begin{array}{c}\text { Volumetric } \\
\text { Output }\left(\mathrm{L} \mathrm{min}^{-1}\right)\end{array}$ & $\begin{array}{c}\text { Thermal } \\
\text { Efficiency }^{[\mathrm{b}]}(\%)\end{array}$ \\
\hline 11.43 & $\mathrm{~A}$ & $2.5\left(3.0 \times 10^{-2}\right)$ & $67.2(2.0)$ & $51.2(1.1)$ & $13,198(51)$ & $94.3 \%(1.5)$ \\
\hline 17.00 & $\mathrm{~B}$ & $2.3\left(3.0 \times 10^{-2}\right)$ & $80.0(1.2)$ & $61.9(0.4)$ & $16,352(33)$ & $92.4 \%(1.5)$ \\
\hline 21.39 & A & $2.1\left(6.0 \times 10^{-2}\right)$ & $118.3(1.4)$ & $102.1(1.1)$ & 14,631 (401) & $96.5 \%(1.5)$ \\
\hline 29.89 & B & $1.9\left(5.0 \times 10^{-2}\right)$ & $140.8(1.0)$ & $125.5(0.6)$ & $17,169(242)$ & $94.98 \%(1.1)$ \\
\hline 42.20 & $\mathrm{C}$ & $1.7\left(3.0 \times 10^{-2}\right)$ & $131.0(1.6)$ & $109.2(0.5)$ & 29,019 (93) & $100.9 \%(0.3)$ \\
\hline 56.27 & $\mathrm{C}$ & $1.4\left(3.0 \times 10^{-2}\right)$ & $180.4(2.3)$ & 159.1 (3.6) & 29,439 (200) & $98.8 \%(2.0)$ \\
\hline
\end{tabular}

${ }^{[a]}$ Measured input calculated using HHV from [5]. ${ }^{[b]}$ Thermal efficiency calculated using HHV from [5]. 


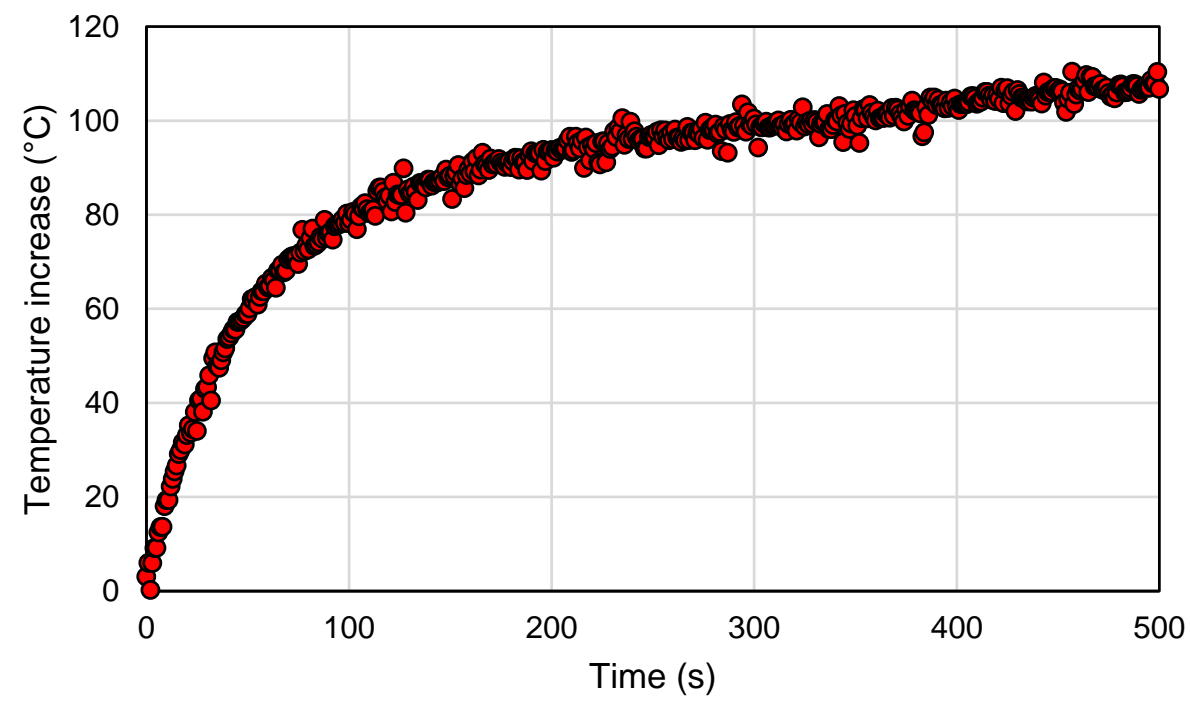

Figure 4. Temperature gain of the exiting air over the course of a test for heater model A at full output.

The measured input energy to heater model $\mathrm{C}$ at full output was significantly lower than its nominal rating of $73.3 \mathrm{~kW}$. Upon investigation of the operational parameters of the tests, it was noted that manifold pressure exhibits a negative trend in relation to the measured input (Figure 5). The temperature of the propane did not vary between any heaters and replicates. This is most likely caused by an improper design of the propane supply of ADL that limits the maximum output due to propane flow and not the heater reaching its rated output.

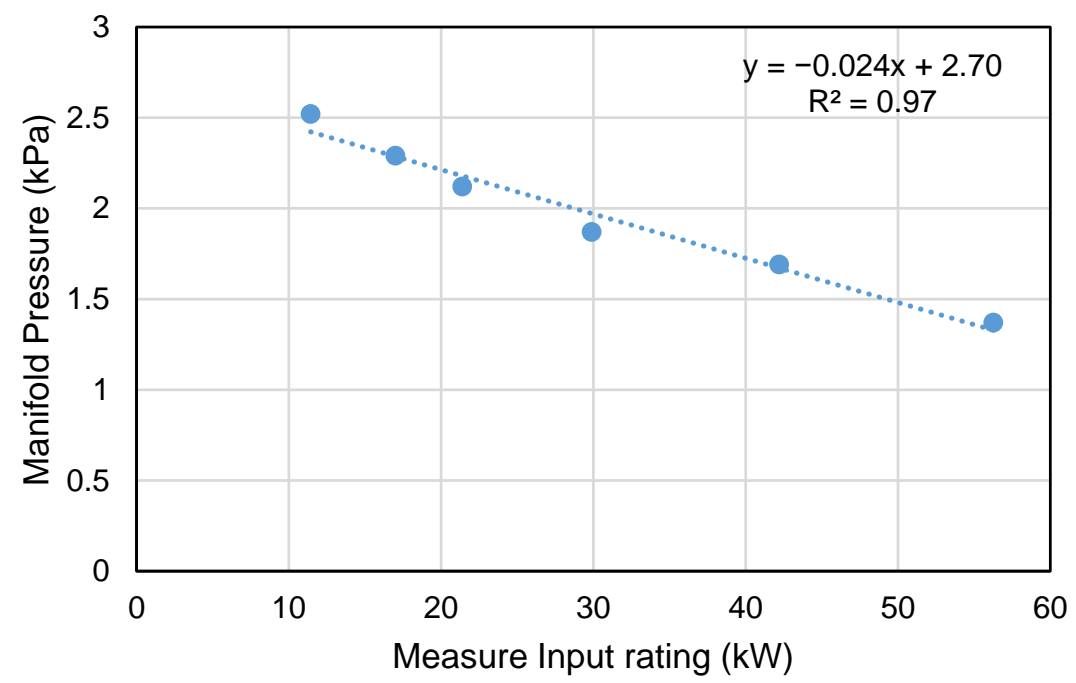

Figure 5. Measured input of propane (x-axis) versus the manifold propane pressure (y-axis).

The sensitivity analysis of the thermal efficiency equation in relation to the HHV was performed for heater model $\mathrm{A}$ at full output. The maximum difference noted in the analysis is between HHV source A $(97.3 \%)$ and D/C $(96.0 \%)$, with source B (96.5\%) falling in-between. While all four sources are relatively similar in value, this highlights the differences in reported values among groups (sources A, B, C) and the federal government (source D). A unified HHV between all organizations is imperative to avoid discrepancies in design and in the rating of all types of propane combustion heaters. 


\subsection{Uncertainty Analysis}

The expanded (coverage factor $=2 ; \sim 95 \%$ confidence interval) uncertainty ranged from $13.1 \%$ (Standard Deviation; $\mathrm{SD}=0.1 \%$ ) to $30.7 \%(\mathrm{SD}=8.0 \%$ ) for the input energy rating 56.3 to $11.4 \mathrm{~kW}$; the $\mathrm{SD}$ is from the multiple replicates of each heater output tested. There is a distinct difference in the variability of the uncertainty between the replications for a heater based on the propane measurement system. The mass flow system had significantly greater variability (Figure 6). The breakdown of the uncertainty contributions (Table 12) demonstrates that for the mass flow system, the propane mass flow and air mass flow are the largest contributors while using volumetric flow measurement, the air mass flow, and change in enthalpy are the largest contributors. Overcoming the variability in the propane mass flow for future tests could require a hardware-based signal conditioning filter to account for the signal noise due to vibrations. Alternatively, extended test duration could be used to reduce variability.

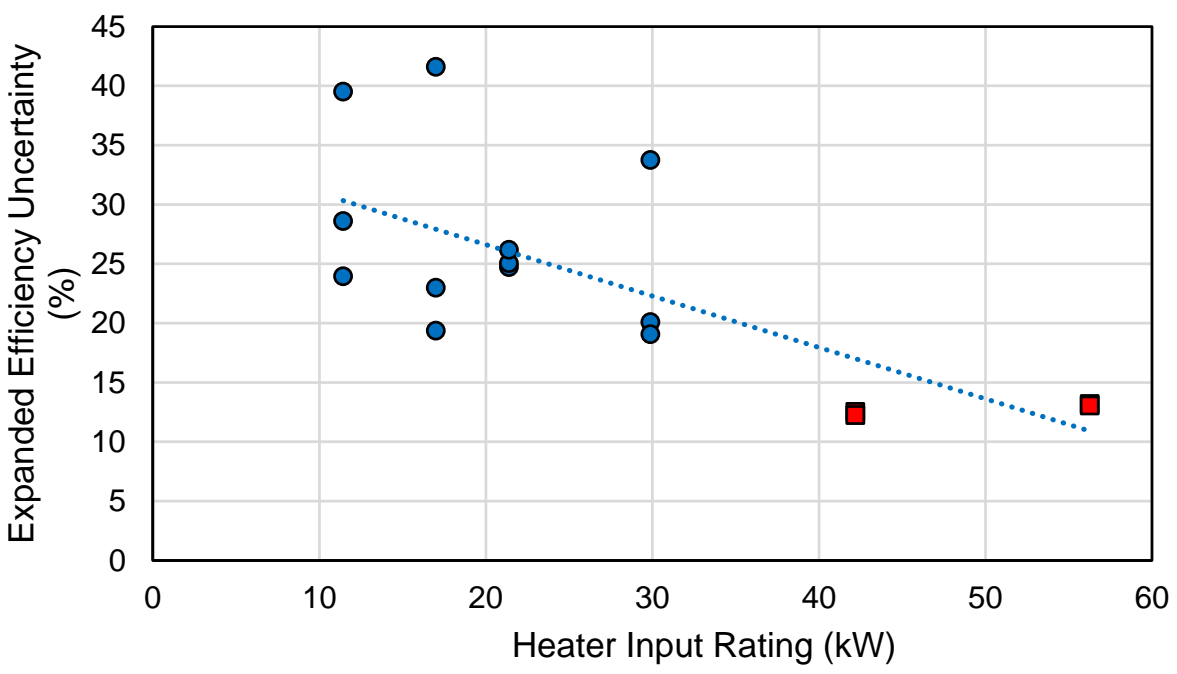

Figure 6. Expanded thermal efficiency (y-axis) versus heater input rating ( $\mathrm{x}$-axis). The blue circles represent the measurements using the mass flow system, and the red squares represent the volumetric flow measurements.

Table 12. Expanded uncertainty component contributions for Equation (20) based on the propane measurement system. The values in parentheses represent 1 standard deviation of the mean.

\begin{tabular}{ccccc}
\hline & Airflow & Change in Enthalpy & Propane Flow & Electrical Consumption \\
\hline Mass flow & $38.0 \%(14.3)$ & $4.0 \%(3.0)$ & $55.9 \%(16.2)$ & $2.1 \%(1.4)$ \\
Volumetric Flow & $80.8 \%(4.9)$ & $17.5 \%(4.5)$ & $0.6 \%(0.2)$ & $1.2 \%(0.3)$ \\
\hline
\end{tabular}

The expanded uncertainty component contributions for the volumetric propane measurement system suggest that if a high accuracy, low flow rate option was feasible, it would reduce the uncertainty considerably. To reduce uncertainty in future experiments, a higheraccuracy pressure transducer and RTD would be warranted.

\subsection{Economics of Heater Efficiency}

The economic estimates for heating the specified building using design conditions show a wide heating cost for a heating season (Table 13). There are a few limitations to the degree-day method for estimating this cost. First, it assumes a constant balance temperature for a building. Balance temperature is the ambient temperature that separates the need for heating or cooling, which is different for the various types of agricultural buildings (livestock versus greenhouse). For livestock buildings, this approach cannot account for the increase in the animal's heat production through a growth cycle and the 
change in sensible heat production with indoor temperature. This economic assessment confirms that the greatest heating cost factor is the minimum ventilation rate, with building internal temperature and insulation level being the other factors impacting cost. It should be cautioned against decreasing the ventilation rate of a building to reduce the seasonal heating cost as air quality and moisture levels will be directly impacted and could negatively impact production within the building. The costs and corresponding energy inputs are higher than reported values from field studies for animal agricultural buildings with similar heat production values per floor area [14-16]. These differences are most likely attributed to the method used and the local weather data differences from the reported study's locations.

Table 13. Economic analysis (values reported in USD) for a general agricultural building for a heating season with a heat production of $1.6 \mathrm{~W} \mathrm{~m}^{-2}$.

\begin{tabular}{ccccccc}
\hline Level on Insulation & $\mathbf{T i}_{\text {high }}$ & $\mathbf{T i}_{\text {medium }}$ & $\mathbf{T i}_{\text {low }}$ & $\mathbf{T i}_{\text {high }}$ & $\mathbf{T i}_{\text {medium }}$ & $\mathbf{T i}_{\text {low }}$ \\
\hline UA $_{\text {low }}$ & $\$ 7059$ & $\$ 6756$ & $\$ 6260$ & $\$ 3844$ & $\$ 3676$ & $\$ 3398$ \\
UA $_{\text {medium }}$ & $\$ 6941$ & $\$ 6644$ & $\$ 6159$ & $\$ 3727$ & $\$ 3564$ & $\$ 3297$ \\
UA $_{\text {high }}$ & $\$ 6794$ & $\$ 6505$ & $\$ 6032$ & $\$ 3579$ & $\$ 3424$ & $\$ 3170$ \\
UA $_{\text {very high }}$ & $\$ 6762$ & $\$ 6475$ & $\$ 6005$ & $\$ 3548$ & $\$ 3395$ & $\$ 3144$ \\
\hline
\end{tabular}

The sensitivity analysis for the scenario regarding heater efficiency (Table 14) shows the economic impact of reducing the DGFCH thermal efficiency by $1 \%$ for the combinations of internal temperature and building envelope insulation level. The range of costs is caused by the different range of supplemental heat needs based on internal temperature and insulation value. The magnitude of the costs would be significantly higher if an AEU efficiency for a heater with a pilot light.

Table 14. Economic cost (values reported in USD) of reducing the DGFCH thermal efficiency by $1 \%$ for a heating season.

\begin{tabular}{cccc}
\hline Level on Insulation & $\mathbf{T i}_{\text {high }}$ & $\mathbf{T i}_{\text {medium }}$ & $\mathbf{T i}_{\text {low }}$ \\
\hline $\mathrm{UA}_{\text {low }}$ & $\$ 72.0$ & $\$ 68.9$ & $\$ 63.9$ \\
$\mathrm{UA}_{\text {medium }}$ & $\$ 70.8$ & $\$ 67.8$ & $\$ 62.8$ \\
$\mathrm{UA}_{\text {high }}$ & $\$ 69.3$ & $\$ 66.4$ & $\$ 61.6$ \\
$\mathrm{UA}_{\text {very high }}$ & $\$ 69.0$ & $\$ 66.1$ & $\$ 61.3$ \\
\hline
\end{tabular}

The methods used to perform this economic analysis could be adapted to a range of scenarios to evaluate utility costs for building types, climates, and construction for a cost estimate. Other methods for estimating heating costs are binning methods, where data is binned by day for heating demand (time and temperature difference). This method has advantages in being able to incorporate livestock heat production curves and variable ventilation rates. The downside is that this method requires extensive calculations for each time period within each day and is not a simple calculation for agriculture professions to estimate heating costs for a building.

\section{Conclusions}

A custom testing apparatus and instrumentation system were developed and evaluated for Direct Gas-Fired Circulating Heaters (DGFCH) commonly used in agricultural buildings. Three DGFCH were used for the evaluation testing of the system. The steadystate thermal efficiency of the tests was determined using data from the testing system and based on calculations from a standard for residential systems [5]. An uncertainty analysis was performed on the thermal efficiency calculation for the given measured inputs. An economic analysis for heating common agricultural buildings was performed. An inadequate propane service limited the systems testing ability for $73 \mathrm{~kW}$ rated heaters. A 
sensitivity analysis of the thermal efficiency in respect to the Higher Heating Value (HHV) results in a maximum difference between sources of HHV of 1.3\% efficiency. This highlights the need for standardization between all organizations involved. The uncertainty of the system ranged from $13.1 \%$ to $30.7 \%$ across the input range of 56.2 to $11.4 \mathrm{~kW}$, respectively. The propane mass was the key source of uncertainty at the lower ratings. A more robust hardware system and longer run times would reduce this key source of uncertainty. At higher input ratings, the mass flow of air was the key source of uncertainty. Reducing this would require the use of higher-accuracy sensors. The economic analysis showed that for a $1 \%$ difference in heater efficiency across the combination of inputs (insulation and inside temperature), the costs per heating season ranges from USD \$61.3 to $\$ 72.0$. Future evolutions of this system are needed to reduce the overall uncertainty in thermal efficiency. It is suggested that a flowmeter with lower minimum flow ratings be used or longer test durations to reduce the main source of uncertainty. Other instrumentation improvements are needed for the output air and velocity measurement in the duct. Overall this system shows a great prospect for testing DGFCH commonly used in agricultural buildings. This study has highlighted the need for standardized procedures for quantifying DGFCH thermal efficiency specific to agricultural applications. The unique nature of these heaters presents challenges for testing and has a large economic impact on the agricultural operation during heating seasons.

Author Contributions: Conceptualization, B.C.S., B.C.R., and S.J.H.; methodology, B.C.S., B.C.R., and S.J.H.; software, B.C.S. and S.J.H.; validation, B.C.S.; formal analysis, B.C.S.; resources, B.C.R.; data curation, B.C.S.; writing—original draft preparation, B.C.S.; writing-review and editing, B.C.S., B.C.R., and S.J.H.; supervision, B.C.R.; project administration, B.C.R.; funding acquisition, B.C.R. All authors have read and agreed to the published version of the manuscript.

Funding: This research is a product of the Iowa Agriculture and Home Economics Experiment Station, Ames, Iowa. Project Number IOW04100 is sponsored by the Hatch Act and State of Iowa funds. The content of this article is, however, solely the responsibility of the authors and does not represent the official views of the USDA.

Institutional Review Board Statement: Not applicable.

Informed Consent Statement: Not applicable.

Data Availability Statement: The data presented in this study are available on request from the corresponding author.

Acknowledgments: The authors would like to thank the contributions of undergraduate assistants, Devri Cliburn and Julia Bowman, for their assistance with the calibration and construction of the testing apparatus.

Conflicts of Interest: The authors declare no conflict of interest. The funders had no role in the design of the study; in the collection, analyses, or interpretation of data; in the writing of the manuscript; or in the decision to publish the results.

\section{References}

1. Albright, L.D. Environment Control for Animals and Plants; American Society of Agricultural and Biological Engineers: St. Joesph, MI, USA, 1990; ISBN 0-929355-08-3.

2. Cui, Y.; Theo, E.; Gurler, T.; Su, Y.; Saffa, R. A Comprehensive Review on Renewable and Sustainable Heating Systems for Poultry Farming. Int. J. Low Carbon Technol. 2020, 15, 121-142. [CrossRef]

3. Midwest Plan Service. Structures and Environment Handbook; MWPS-1-TSM; Midwest Plan Service: Ames, IA, USA, 1983.

4. Sanford, S. Greenhouse Unit Heaters-Types, Placement \& Efficiency; University of Wisconsin Cooperative Extension: Madison, WI, USA, 2011; p. 6.

5. ANSI/ASHRAE. Method of Testing for Annual Utilization Efficiency of Residential Central Furnances and Boilers; ASHRAE: Atlanta, GA, USA, 2017.

6. Hoff, S.J.; Utrecht, D.V.; Harmon, J.D.; Mangold, D.W. A General Purpose Laboratory for Evaluating Livestock Ventilation Systems. Appl. Eng. Agric. 2000, 16, 701-710. [CrossRef]

7. Doebelin, E.O. Measurement Systems: Application and Design, 5th ed.; McGraw-Hill: New York, NY, USA, 2004; ISBN 0-07-243886-X.

8. ASHRAE. ASHRAE Handbook; ASHRAE: Atlanta, GA, USA, 2013. 
9. $\quad$ Parker, B.F.; Lindley, M.R.; Colliver, D.G.; Murphy, W.E. Thermal Performance of Three Solar Air Heaters. Sol. Energy 1993, 51, 467-479. [CrossRef]

10. Saxena, A.; Verma, P.; Srivastava, G.; Kishore, N. Design and Thermal Performance Evaluation of an Air Heater with Low Cost Thermal Energy Storage. Appl. Therm. Eng. 2020, 167, 114768. [CrossRef]

11. Energy Information Administration (EIA). EIA Energy Units and Calculators Explained-U.S. Available online: https://www. eia.gov / energyexplained/units-and-calculators / (accessed on 21 January 2021).

12. REGO. LP-Gas Serviceman's Manual; REGO: Elon, NC, USA, 2020.

13. Juanicó, L.E.; González, A.D. Thermal Efficiency of Natural Gas Balanced-Flue Space Heaters: Measurements for Commercial Devices. Energy Build. 2008, 40, 1067-1073. [CrossRef]

14. Sharpe, K.T.; Reese, M.H.; Buchanan, E.S.; Tallaksen, J.E.; Janni, K.A.; Johnston, L.J. Electrical and Thermal Energy Consumption in Midwest Commercial Swine Facilities. Appl. Eng. Agric. 2018, 34, 857-864. [CrossRef]

15. Barber, E.M.; Classen, H.L.; Thacker, P.A. Energy Use in the Production and Housing of Poultry and Swine-An Overview. Can. J. Anim. Sci. 1989, 69, 7-21. [CrossRef]

16. Fernandez, M.D.; Losada, E.; Ortega, J.A.; Arango, T.; Ginzo-Villamayor, M.J.; Besteiro, R.; Lamosa, S.; Barrasa, M.; Rodriguez, M.R. Energy, Production and Environmental Characteristics of a Conventional Weaned Piglet Farm in North West Spain. Agronomy 2020, 10, 902. [CrossRef] 